\title{
Asthma: Gln27Glu and Arg16Gly polymorphisms of the beta2-adrenergic receptor gene as risk factors
}

Ana Carolina Zimiani de Paiva ${ }^{1 \dagger}$, Fernando Augusto de Lima Marson ${ }^{1,2^{*}}{ }^{+}$, José Dirceu Ribeiro ${ }^{2}$ and Carmen Sílvia Bertuzzo ${ }^{1}$

\begin{abstract}
Background: Asthma is caused by both environmental and genetic factors. The ADRB2 gene, which encodes the beta 2-adrenergic receptor, is one of the most extensively studied genes with respect to asthma prevalence and severity. The Arg16Gly (+46A $>$ G) and Gln27Glu (+79C > G) polymorphisms in the ADRB2 gene cause changes in the amino acids flanking the receptor ligand site, altering the response to bronchodilators and the risk of asthma through complex pathways. The ADRB2 polymorphisms affect beta-adrenergic bronchodilator action and are a tool to identify at-risk populations.
\end{abstract}

Objective: To determine the frequency of these two polymorphisms in allergic asthma patients and healthy subjects and to correlate these data with the occurrence and severity of asthma.

Methods: Eighty-eight allergic asthma patients and 141 healthy subjects were included in this study. The ADRB2 polymorphisms were analyzed using the amplification-refractory mutation system - polymerase chain reaction (ARMS-PCR) technique. The statistical analysis was performed with the SPSS 21.0 software using the Fisher's Exact and $X^{2}$ tests.

Results: The ADRB2 polymorphisms were associated with asthma occurrence. The Arg16Arg, Gln27Gln and Gln27Glu genotypes were risk factors; the odds ratios were $6.782(\mathrm{Cl}=3.07$ to 16.03$), 2.120(\mathrm{Cl}=1.22$ to 3.71$)$ and $8.096(\mathrm{Cl}=3.90$ to 17.77$)$, respectively. For the Gly $16 \mathrm{Gly}$ and Glu27Glu genotypes, the odds ratios were 0.312 $(\mathrm{Cl}=0.17$ to 0.56$)$ and $0.084(\mathrm{Cl}=0.04$ to 0.17$)$, respectively. The haplotype analysis showed that there were associations between the following groups: Arg16 Arg-Gln27Gln (OR=5.108, Cl=1.82 to 16.37), Gly16Gly-Glu27Glu $(\mathrm{OR}=2.816, \mathrm{Cl}=1.25$ to 6.54$)$, Arg16Gly-GIn27Glu (OR $=0.048, \mathrm{Cl}=0.01$ to 0.14$)$ and Gly16Gly-GIn27Glu (OR=0.1036, $\mathrm{Cl}=0.02$ to 0.39 ). The polymorphism $\mathrm{G} \ln 27 \mathrm{Glu}$ was associated with asthma severity, as the Gln27Gln genotype was a risk factor for severe asthma (OR $=2.798, \mathrm{Cl}=1.099$ to 6.674$)$ and the $\mathrm{Gln} 27 \mathrm{Glu}$ genotype was a protective factor for mild $(\mathrm{OR}=3.063, \mathrm{Cl}=1.037$ to 9.041$)$ and severe $(\mathrm{OR}=0.182, \mathrm{Cl}=0.048$ to 0.691$)$ asthma.

Conclusions: The Arg16Gly and Gln27Glu polymorphisms in the ADRB2 gene are associated with asthma presence and severity.

Keywords: Asthma, ADRB2 gene, Lung disease, Arg16Gly, Gln27Glu

\footnotetext{
* Correspondence: fernandolimamarson@hotmail.com

${ }^{\dagger}$ Equal contributors

${ }^{1}$ Department of Medical Genetics, Faculty of Medical Sciences, State

University of Campinas (Unicamp), Campinas, São Paulo zip code: 13081-970,

Brazil

${ }^{2}$ Department of Pediatrics, Faculty of Medical Sciences, State University of

Campinas (Unicamp), Tessália Vieira de Camargo, 126, Campinas, SP zip code:

13081-970, Brazil
}

\section{Biomed Central}

(c) 2014 de Paiva et al.; licensee BioMed Central Ltd. This is an Open Access article distributed under the terms of the Creative Commons Attribution License (http://creativecommons.org/licenses/by/2.0), which permits unrestricted use, distribution, and reproduction in any medium, provided the original work is properly credited. The Creative Commons Public Domain Dedication waiver (http://creativecommons.org/publicdomain/zero/1.0/) applies to the data made available in this article, unless otherwise stated. 


\section{Background}

Asthma is a chronic inflammatory disease of the airways defined by clinical, physiological and pathological characteristics. The main traits of allergic asthma in children are shortness of breath, wheezing, obstruction and inflammation of airways, and atopy [1]. Genetically, asthma is a complex disease in which multiple genes interact among themselves and with the environment [1].

Asthma affects approximately 300 million people worldwide ( 1 to $18 \%$ of the population in different countries) $[2,3]$ and is associated with 250,000 deaths per year. In Brazil, $20 \%$ of the population is affected, with approximately 350,000 hospitalizations per year or $2.3 \%$ of the hospital admissions in the Public Health System [4]. Asthma-related mortality has been growing over the last 10 years but does not correlate with disease prevalence. Asthma causes 5 to $10 \%$ of the respiratory-related deaths, with a high number of deaths occurring at home [4].

There are several factors that influence the development of asthma, including genes that predispose an individual to atopy and airway hyperresponsiveness; obesity; sex; and environmental causes, such as allergens (house dust mites, animal fur, and fungi), viral infections, occupational sensitizers, tobacco smoke, air pollution and eating habits. Additionally, some immunological characteristics, such as immune system maturation and the number of exposures to infectious agents during the first years of life, are factors that affect the risk of developing asthma. Another characteristic linked to an increased risk of asthma is ethnicity, which reflects vast genetic differences as well as significant social and economic variations that affect exposure to allergens and access to health services [1,5-10].

Asthma severity is assessed by analyzing the frequency and intensity of symptoms and examining pulmonary function. Based on these criteria, asthma is classified as either intermittent or persistent asthma, the latter of which can be mild, moderate or severe [1].

The pathophysiological characteristic present in asthmatic patients is bronchial inflammation, which is the result of complex interactions between the inflammatory cells, cell-derived mediators, and airway cells [11].

An important factor studied in asthma-related research is the beta-2-adrenergic receptor, which is encoded by the $A D R B 2$ gene [12]. The $A D R B 2$ gene is a small gene on chromosome 5q31-q32 [13], a region genetically linked to asthma [14]. Nine coding polymorphisms were originally described in the $A D R B 2$ gene, including four that cause non-synonymous changes in the amino acid sequence (Gly16Arg, Gln27Glu, Val34Met and Thr164Ile).

The $\beta 2$ receptors $(\beta 2-\mathrm{AR})$ are widely expressed in the respiratory tract, particularly in the airway smooth muscles [12,15-17]. They are members of a family of seventransmembrane receptors [18] and are 413 amino acids long [19]. Once activated, the most clinically relevant effect of the $\beta 2$-ARs in the pulmonary smooth muscle is relaxation, which may be caused by $\beta 2$-AR agonists. Chronic exposure to these agonists leads to a significant reduction in the number of $\beta 2$-ARs on the cell surface $[16,17]$. This down-regulation is reflected in vivo as a tolerance to the effects of the $\beta 2-\mathrm{AR}$ agonists [20-24].

In airway smooth muscle cells, the $\beta 2$-AR agonists activate adenylyl cyclase through membrane-coupled Gproteins; this activation increases the intracellular cAMP (cyclic adenosine monophosphate) concentration and relaxes the airway tonus [25]. The $\beta 2$-AR agonists may also affect $\mathrm{Ca}^{2+}$ and $\mathrm{K}^{+}$channels in smooth muscles and lead to relaxation independently of cAMP [26].

The two most frequent deleterious polymorphisms in the ADRB2 gene are Arg16Gly (+46A > G; rs1042713) and Gln27Glu $(+79 \mathrm{C}>\mathrm{G}$; rs1042714). The Arg16Gly and Gln27Glu polymorphisms are near the receptor's ligandbinding site [27]. The frequency of Gly16 is greater than that of Arg16, which is considered the normal allele. The allelic frequency described for the Arg16 variant ranges from $67 \%$ to $72 \%$ in different populations $[28,29]$.

In the Brazilian population, to the best of our knowledge, there are no studies on asthma and the frequency of the Arg16Gly and Gln27Glu polymorphisms that take into account asthma risk and clinical severity. Therefore, our study included asthma patients and healthy subjects, and the associations between both groups and each polymorphism were assessed during the same analysis. The clinical evaluation of asthma severity was associated with the Arg16Gly and Gln27Glu polymorphisms.

\section{Methods}

Patients and healthy controls

A cross-sectional prospective study including 88 asthmatic patients was conducted at the Pediatric Pulmonology Clinic at the University Hospital.

The mean age was $10.38( \pm 2.93)$ years with a range of 7 to 16 years. All patients enrolled had allergic asthma according to the GINA criteria [1]. The allergy classification was defined by co-occurrence with asthma, atopic dermatitis, a positive skin test in response to allergens (dust mites, fungi, or house dust components), increased IgE serum levels, greater than $4 \%$ eosinophils in the peripheral blood in the absence of parasites and clinical history. All patients were subjected to three parasitological stool examinations three months prior to the onset of the study and were treated with albendazole as necessary.

The control group was composed of 141 healthy subjects ranging in age from 18 to 25 years who donated blood at the Unicamp University Hospital. In our data, all controls were examined for allergic asthma and a family history of asthma. In the case of a family history of asthma, the subject was excluded from our control group. 
Table 1 Association of ADRB2 polymorphisms [Arg16Gly (c.46A > G) and Gln27Glu (c.79C > G)] with asthma risk

\begin{tabular}{|c|c|c|c|c|c|}
\hline Polymorphism & Genotype & Patient & Control & OR & $95 \% \mathrm{Cl}$ \\
\hline \multirow[t]{4}{*}{ Arg16Gly (c.46A > G) ${ }^{1,2}$} & Homozygous Arg16 & 28 & 9 & 6.782 & $3.07-16.03$ \\
\hline & Heterozygous & 38 & 59 & 1.056 & $0.61-1.81$ \\
\hline & Homozygous Gly16 & 22 & 73 & 0.312 & $0.17-0.56$ \\
\hline & Total & 88 & 141 & & \\
\hline \multirow[t]{4}{*}{ Gln27Glu(c.79C > G) ${ }^{3,4}$} & Homozygous Gln27 & 41 & 41 & 2.120 & $1.22-3.71$ \\
\hline & Heterozygous & 36 & 11 & 8.096 & $3.90-17.77$ \\
\hline & Homozygous Glu27 & 11 & 89 & 0.084 & $0.04-0.17$ \\
\hline & Total & 88 & 141 & & \\
\hline
\end{tabular}

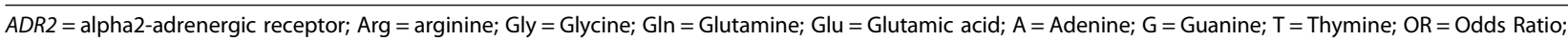
$\mathrm{Cl}=$ Confidence Interval.

Hardy-Weinberg equilibrium was calculated using the OEGE tool (http://www.oege.org/software/hardy-weinberg.html), being: $\left(1\right.$ - patient) $\mathrm{X}^{2}=1.54$, $\mathrm{p}$-value $>0.05$; $\left(2\right.$ - control) $X^{2}=0.48, p$-value $>0.05 ;(3$ - patient $) X^{2}=0.41, p$-value $>0.05 ;\left(4\right.$ - control) $X^{2}=95.62, p$-value $<0.001$.

The OR was calculated using the Open-Epi tool (http://www.openepi.com). The OR and $95 \% \mathrm{Cl}$ values were obtained using the Mild-P test. For all data analyzed, $a=0.05$ was used. The significant $p$-values are in bold.

The project was approved by the University Ethics Committee (\#267/2005), and all patients and/or their guardians signed an informed consent.

\section{Arg16Gly and GIn27Glu polymorphism analyses}

Genomic DNA was extracted from the venous blood samples using phenol-chloroform. The DNA concentration was determined using a GE NanoVue ${ }^{\text {rm }}$ Spectrophotometer (GE Healthcare Biosciences, Pittsburgh, USA), and $50 \mathrm{ng} / \mathrm{mL}$ of each sample was used for the analysis.

Polymorphism analysis of the ADRB2 gene was performed by the polymerase (PCR) allele specific (ARMS) reaction $[30,31]$. Four reactions were performed (ARMS1a,

Table 2 Association of ADRB2 polymorphism [Arg16Gly (c.46A > G) and GIn27Glu (c.79C > G)] combinations with asthma risk

\begin{tabular}{lccccc}
\hline Polymorphisms & $\begin{array}{c}\text { Genotypes } \\
\text { groups }\end{array}$ & Patient & Control & OR & $\mathbf{9 5 \% ~ C l}$ \\
\hline Gly16 - Gln27 & 1 & 19 & 23 & 1.411 & $0.71-2.79$ \\
Arg16 - Glu27 & 1 & 10 & 0 & - & - \\
Arg16 - Gln27 & 0 & 14 & 5 & $\mathbf{5 . 1 0 8}$ & $\mathbf{1 . 8 2 - 1 6 . 3 7}$ \\
Gly16 - Glu27 & 2 & 17 & 11 & $\mathbf{2 . 8 1 6}$ & $\mathbf{1 . 2 5}-\mathbf{6 . 5 4}$ \\
Het16 - Gln27 & 0 & 10 & 12 & 1.376 & $0.55-3.38$ \\
Het16 - Glu27 & 1 & 9 & 0 & - & - \\
Het16 - Het27 & 0 & 3 & 60 & $\mathbf{0 . 0 4 8}$ & $\mathbf{0 . 0 1 - 0 . 1 4}$ \\
Arg16 - Het27 & 0 & 4 & 4 & 1.627 & $0.36-7.39$ \\
Gly16 - Het27 & 1 & 2 & 26 & $\mathbf{0 . 1 0 3 6}$ & $\mathbf{0 . 0 2 - 0 . 3 9}$
\end{tabular}

$A D R B 2$ = alpha2-adrenergic receptor; Arg = arginine; Gly = Glycine; $\mathrm{Gln}=$ Glutamine; $\mathrm{Glu}=$ Glutamic acid; $\mathrm{A}=$ Adenine; $\mathrm{G}=$ Guanine; $\mathrm{T}=$ Thymine; $\mathrm{Het}=$ heterozygotes; $\mathrm{OR}=$ Odds Ratio; $\mathrm{Cl}=$ Confidence Interval.

*The groups were created by counting each homozygous guanine allele at the Arg16Gly (c.46A > G) and GIn27Glu (c.79C > G) polymorphisms: (0) Arg16Arg + Gln27GIn genotype combination; (1) Gly16Gly or Glu27Glu genotype presence; (2) Gly16Gly + Glu27Glu genotype combination.

The OR was calculated using the Open-Epi tool (http://www.openepi.com). The OR and $95 \% \mathrm{Cl}$ values were obtained using the Mild-P test. For all data analyzed, $a=0.05$ was used. The significant $p$-values are in bold.
ARMS2a, ARMS1b and ARMS2b), each containing a common primer (5'-AGG CCC ATG ACC AGA TCA GCA CAG GCC AG-3') and one allele-specific primer [ARMS1a (5' - ACG GCA GCG CCT TCT TGC TGG CAC CCA AAA-3'), ARMS2a (5'-ACG GCA GCG CCT TCT TGC TGG CAC CCA AAG-3'), ARMS1b (5'-GCC ATG CGC CGG ACC ACG ACG TCA CGC ATC-3') and ARMS2b (5'-GCC ATG CGC CGG ACC ACG ACG TCA CGC AAG-3')]. All four reactions were performed under the same conditions. Each $10 \mu \mathrm{L}$ reaction contained $1 \times 4$ PCR buffer, $200 \mu \mathrm{M}$ of dNTPs, $5.0 \mathrm{nM}$ of $\mathrm{MgCl}_{2}, 0.4 \mathrm{U}$ of Taq polymerase, $0.2 \mathrm{pmol}$ of each primer and $1.0 \mu \mathrm{L}$ (approximately $50 \mathrm{ng}$ ) of genomic DNA.

The PCR amplification conditions consisted of $5 \mathrm{mi}-$ nutes at $94^{\circ} \mathrm{C}$ followed by 35 cycles of $94^{\circ} \mathrm{C}$ for 1 minute, $60^{\circ} \mathrm{C}$ (46A or G, $16 \mathrm{Arg}$ or Gly) or $67^{\circ} \mathrm{C}$ (70C or G, 27 Gln or Glu), and $72^{\circ} \mathrm{C}$ for 1 minute followed by $72^{\circ} \mathrm{C}$ for 10 minutes.

The amplicons were subjected to electrophoresis on a $12 \%$ acrylamide gel and stained with ethidium bromide.

\section{Statistical analysis}

Statistical analysis was performed using the software SPSS (Statistical Package for the Social Sciences) version 21.0 (Armonk, NY: IBM Corp), Open Epi [32] and R version 2.12 (Comprehensive R Archive Network, 2011). The statistical power calculation for the sample was performed using the GPOWER 3.1 software [33] and demonstrated statistical power above $80 \%$ for the analysis conducted. An alpha level of 0.05 was used in all of the data analyses.

The Fisher's Exact and chi-squared $\left(x^{2}\right)$ tests were performed to determine the association between the polymorphisms analyzed and the presence and severity of asthma.

The Hardy-Weinberg equilibrium was calculated using the Online Encyclopedia for Genetic Epidemiology (OEGE) software (http://www.oege.org/software/hardy-weinberg.html). 
Table 3 Association of ADRB2 polymorphisms [Arg16Gly (c.46A > G) and Gln27Glu (c.79C > G)] with asthma risk based on the presence of Guanine alleles

\begin{tabular}{ccccc}
\hline Genotypes groups* $^{*}$ & Patient & Control & OR & $\mathbf{9 5 \% ~ C l}$ \\
\hline 0 & 31 & 81 & $\mathbf{0 . 4 0 5}$ & $\mathbf{0 . 2 3 - 0 . 7 0}$ \\
1 & 40 & 49 & 1.562 & $0.90-2.70$ \\
2 & 17 & 11 & $\mathbf{2 . 8 1 6}$ & $\mathbf{1 . 2 5}-6.54$ \\
\hline
\end{tabular}

$A D R B 2$ = alpha2-adrenergic receptor; Arg = arginine; Gly = Glycine;

$\mathrm{Gln}=$ Glutamine; Glu = Glutamic acid; $\mathrm{A}=$ Adenine; $\mathrm{G}=$ Guanine; $\mathrm{T}=$ Thymine; $\mathrm{OR}=$ Odds Ratio; $\mathrm{Cl}=$ Confidence Interval.

*The groups were created by counting each homozygous guanine allele at the Arg16Gly (c.46A > G) and GIn27Glu (c.79C > G) polymorphisms: (0) Arg16Arg + Gln27GIn genotype combination; (1) Gly16Gly or Glu27Glu genotype presence; (2) Gly16Gly + Glu27Glu genotype combination.

The OR was calculated using the Open-Epi tool (http://www.openepi.com). The $\mathrm{OR}$ and $95 \% \mathrm{Cl}$ values were obtained using the Mild-P test. For all data analyzed, $a=0.05$ was used. The significant $p$-values are in bold.

To calculate the sample power, the GPower*3.1.6 program was used [33]. In the calculation, we considered the minor allele frequency (MAF) to establish the sample size. According to the NCBI (National Center for Biotechnology Information - http://www.ncbi.nlm.nih.gov/) database, the frequencies of the $\mathrm{A}$ and $\mathrm{C}$ alleles at the $46 \mathrm{~A}>\mathrm{G}$ and $79 \mathrm{C}>\mathrm{G}$ polymorphisms were 0.471 and 0.238 , respectively. With the frequency of $0.238, \alpha=0.05$ and $\beta=0.80$, the power calculation estimates the patient sample size should be 193 patients based on using a $\chi^{2}$ test for the comparisons to be performed. In our study, we included 229 patients and controls and with our population obtained a $\beta$-error of 0.846 .
To evaluate the genetic interactions among the polymorphisms in our sample, we used the Multifactor Dimensionality Reduction (MDR) model, which is a nonparametric and genetic model-free data mining tool for nonlinear interaction identification among genetic and environmental attributes [34-36]. To adjust the results for multiple comparisons, we performed a MDR permutation test on our data using 100,000 permutations.

\section{Results}

The allelic frequencies for the Arg16Gly polymorphism were 94 (53.4\%) and $82(46.6 \%)$ for the A and G alleles, respectively, in the asthma group and 77 (27.3\%) and 205 (72.7\%), respectively, in the healthy subjects. For the Gln27Glu polymorphism, the allelic frequencies for the $\mathrm{C}$ and $\mathrm{G}$ alleles were 118 (67.0\%) and 48 (33.0\%), respectively, in the asthma group and 93 (33.0\%) and 189 (67\%), respectively, in the healthy subjects.

The polymorphisms are in Hardy-Weinberg equilibrium except for the Gln27Glu polymorphism, which is not in equilibrium in the healthy subject population. The complete genotype data and the Hardy-Weinberg equilibriums are shown in Table 1.

In our data, the $A D R B 2$ polymorphisms were associated with the occurrence of asthma. For the Arg16Arg, Gln27Gln and Gln27Glu genotypes, the risk factor odds ratios were $6.782(\mathrm{CI}=3.07$ to 16.03$), 2.120(\mathrm{CI}=1.22$ to $3.71)$ and $8.096(\mathrm{CI}=3.90$ to 17.77$)$, respectively. For the Gly16Gly and Glu27Glu genotypes, the odds ratios were

Table 4 Association of asthma severity with ADRB2 polymorphisms [Arg16Gly (c.46A > G) and Gln27Glu (c.79C > G)]

\begin{tabular}{|c|c|c|c|c|c|c|c|c|c|}
\hline \multirow[t]{2}{*}{ Severity } & \multicolumn{7}{|c|}{ Arg16Gly (c.46A > G) polymorphism } & \multirow[t]{2}{*}{$x^{2}$} & \multirow[t]{2}{*}{ p-value } \\
\hline & Arg16Arg & OR $(95 \% \mathrm{Cl})$ & Arg16Gly & OR $(95 \% \mathrm{Cl})$ & Gly16Gly & OR $(95 \% \mathrm{Cl})$ & Total & & \\
\hline Severe & $14(37.8 \%)$ & $1.258(0.508-3.114)$ & $3(8.1 \%)$ & $0.25(0.064-0.966)$ & $20(54.1 \%)$ & $1.672(0.698-4.003)$ & $37(100 \%)$ & 4.674 & 0.322 \\
\hline Moderate & $7(33.3 \%)$ & $0.909(0.319-2.587)$ & $5(23.8 \%)$ & $1.625(0.484-5.454)$ & $9(42.9 \%)$ & $0.703(0.259-1.906)$ & $21(100 \%)$ & & \\
\hline \multirow[t]{3}{*}{ Mild } & $8(32 \%)$ & $0.829(0.306-2.246)$ & $7(28 \%)$ & $2.431(0.771-7.665)$ & $10(40 \%)$ & $0.667(0.258-1.726)$ & $25(100 \%)$ & & \\
\hline & \multicolumn{7}{|c|}{ Gln27Glu (c.79C > G) polymorphism } & & \\
\hline & Gln27Gln & OR $(95 \% \mathrm{Cl})$ & Gln27Glu & OR $(95 \% \mathrm{Cl})$ & Glu27Glu & OR $(95 \% \mathrm{Cl})$ & Total & & \\
\hline Severe & $25(67.6 \%)$ & $2.708(1.099-6.674)$ & $3(8.1 \%)$ & $0.182(0.048-0.691)$ & $9(24.3 \%)$ & $1.023(0.372-2.812)$ & $37(100 \%)$ & 8.285 & 0.082 \\
\hline Moderate & $10(47.6 \%)$ & $0.701(0.26-1.892)$ & $6(28.6 \%)$ & $1.667(0.534-5.197)$ & $5(23.8 \%)$ & $0.979(0.307-3.124)$ & $21(100 \%)$ & & \\
\hline \multirow[t]{3}{*}{ Mild } & $10(40 \%)$ & $0.438(0.168-1.141)$ & $9(36 \%)$ & $3.063(1.037-9.041)$ & $6(24 \%)$ & $0.9925(0.331-2.973)$ & $25(100 \%)$ & & \\
\hline & \multicolumn{7}{|c|}{ Arg16Gly (c.46A > G) and Gln27Glu (c.79C > G) polymorphisms in combination* } & & \\
\hline & 0 & OR $(95 \% \mathrm{Cl})$ & 1 & OR $(95 \% \mathrm{Cl})$ & 2 & OR $(95 \% \mathrm{Cl})$ & Total & & \\
\hline Severe & $12(32.4 \%)$ & $0.571(0.232-1.406)$ & $21(56.8 \%)$ & $1.706(0.712-4.086)$ & $4(10.8 \%)$ & $0.994(0.247-4)$ & 37 (100\%) & 1.908 & 0.753 \\
\hline Moderate & $9(42.9 \%)$ & $1.188(0.435-3.241)$ & $10(47.6 \%)$ & $0.909(0.338-2.448)$ & $2(9.5 \%)$ & $0.827(0.158-4.331)$ & $21(100 \%)$ & & \\
\hline Mild & 12 (48\%) & $1.626(0.629-4.205)$ & $10(40 \%)$ & $0.581(0.224-1.504)$ & $3(12 \%)$ & $1.182(0.271-5.154)$ & 25 (100\%) & & \\
\hline
\end{tabular}

ADRB2 = alpha2-adrenergic receptor; Arg = arginine; Gly = Glycine; Gln = Glutamine; Glu = Glutamic acid; $A=$ Adenine; $\mathrm{G}=\mathrm{Guanine}$ T = Thymine; OR = Odds Ratio; $\mathrm{Cl}=$ Confidence Interval.

*The groups were created by counting each homozygous guanine allele at the Arg16Gly (c.46A > G) and Gln27Glu (c.79C > G) polymorphisms: (0) Arg16Arg + Gln27GIn genotype combination; (1) Gly16Gly or Glu27Glu genotype presence; (2) Gly16Gly + Glu27Glu genotype combination.

The OR was calculated using the Open-Epi tool (http://www.openepi.com). The OR and $95 \% \mathrm{Cl}$ values were obtained using the Mild-P test and in the table the $X^{2}$ value is shown. For all data analyzed, $a=0.05$ was used. The significant $p$-values are in bold. 
$0.312(\mathrm{CI}=0.17$ to 0.56$)$ and $0.084(\mathrm{CI}=0.04$ to 0.17$)$, respectively. For more details, consult Tables 1 and 2.

The haplotype analysis showed associations between the following polymorphisms: Arg16Arg-Gln27Gln (OR = 5.108, $\mathrm{CI}=1.82$ to 16.37), Gly16Gly-Glu27Glu (OR = 2.816, $\mathrm{CI}=1.25$ to 6.54$)$, Arg16Gly-Gln27Glu $(\mathrm{OR}=0.048$, $\mathrm{CI}=0.01$ to 0.14$)$ and Gly16Gly-Gln27Glu (OR $=0.1036$, $\mathrm{CI}=0.02$ to 0.39 ). The complete haplotype analysis is shown in Table 3. To confirm our data, the groups with the highest observed frequency were analyzed in comparison with all of the other possible groups. The complete group data can be found in Table 4.

All of the data and the comparisons between the groups can be found in Figure 1.

When asthma severity was taken into account, the polymorphism Gln27Glu was a risk factor for severe asthma when the Gln27Gln genotype was present $(\mathrm{OR}=2.798$, $\mathrm{CI}=1.099$ to 6.674$)$ and a protective factor for mild (OR =
3.063, $\mathrm{CI}=1.037$ to 9.041$)$ and severe asthma $(\mathrm{OR}=0.182$, $\mathrm{CI}=0.048$ to 0.691 ) when the Gln27Glu genotype was present.

The MDR analysis showed evidence of an interaction between Arg16Gly and Gln27Glu as risk factors for asthma [Testing Balance Accuracy $=0.7727 ; \mathrm{p}$-value $=0.0000$ 0.0010; Ratio $=0.6377$ ] (Figure 2).

\section{Discussion}

Pharmacotherapy that is tailored to an asthmatic patient's genotype should result in a clinically significant increase in efficacy and reduction in adverse events and, therefore, have an important role in disease severity [37]. The $\beta$-agonists are the most commonly used agents for asthma treatment [1]. Polymorphisms in the ADRB2 gene have been screened and found to be associated with altered expression, function and regulation of the $\beta 2$ receptor. These types of genetically based differences

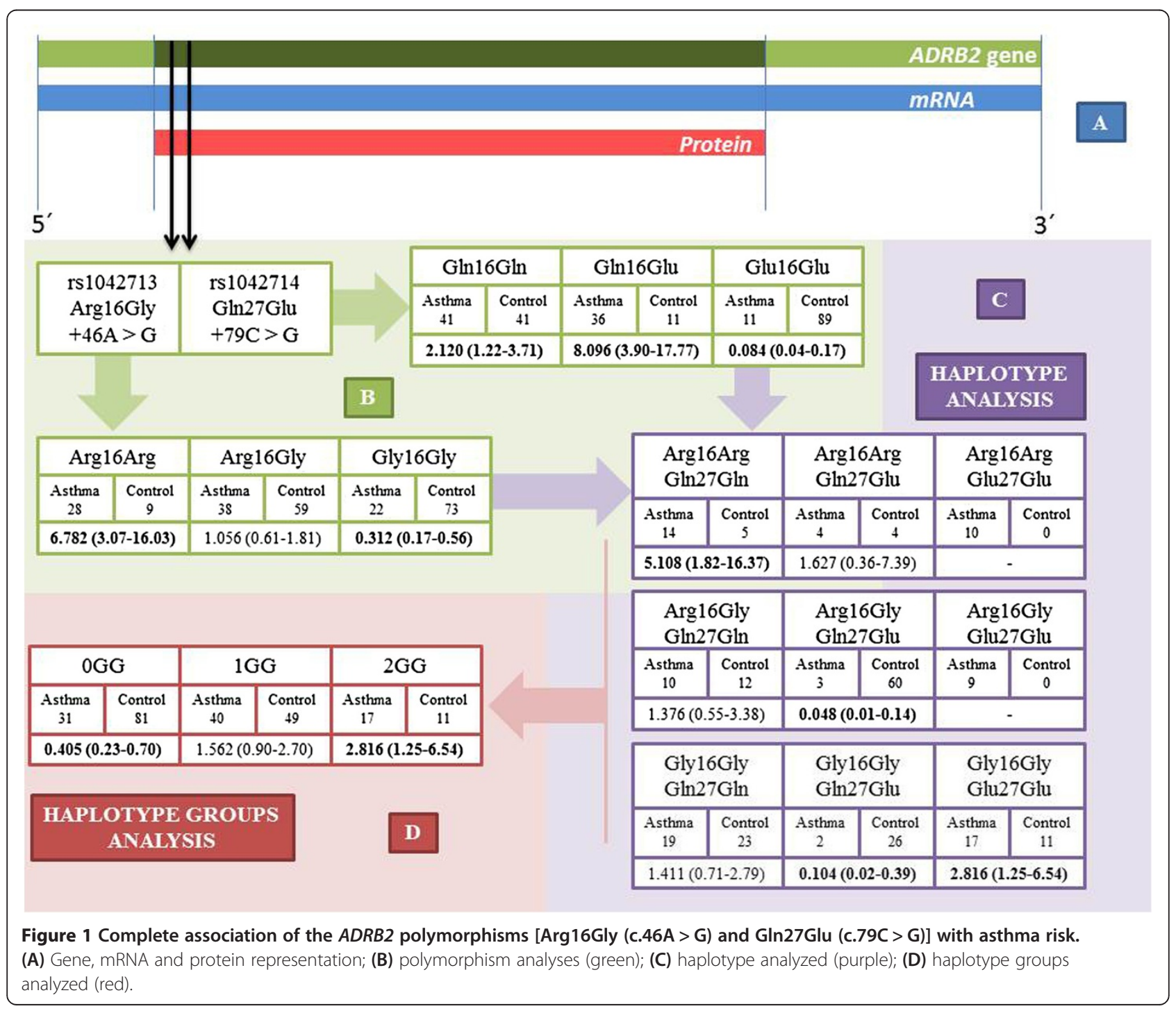




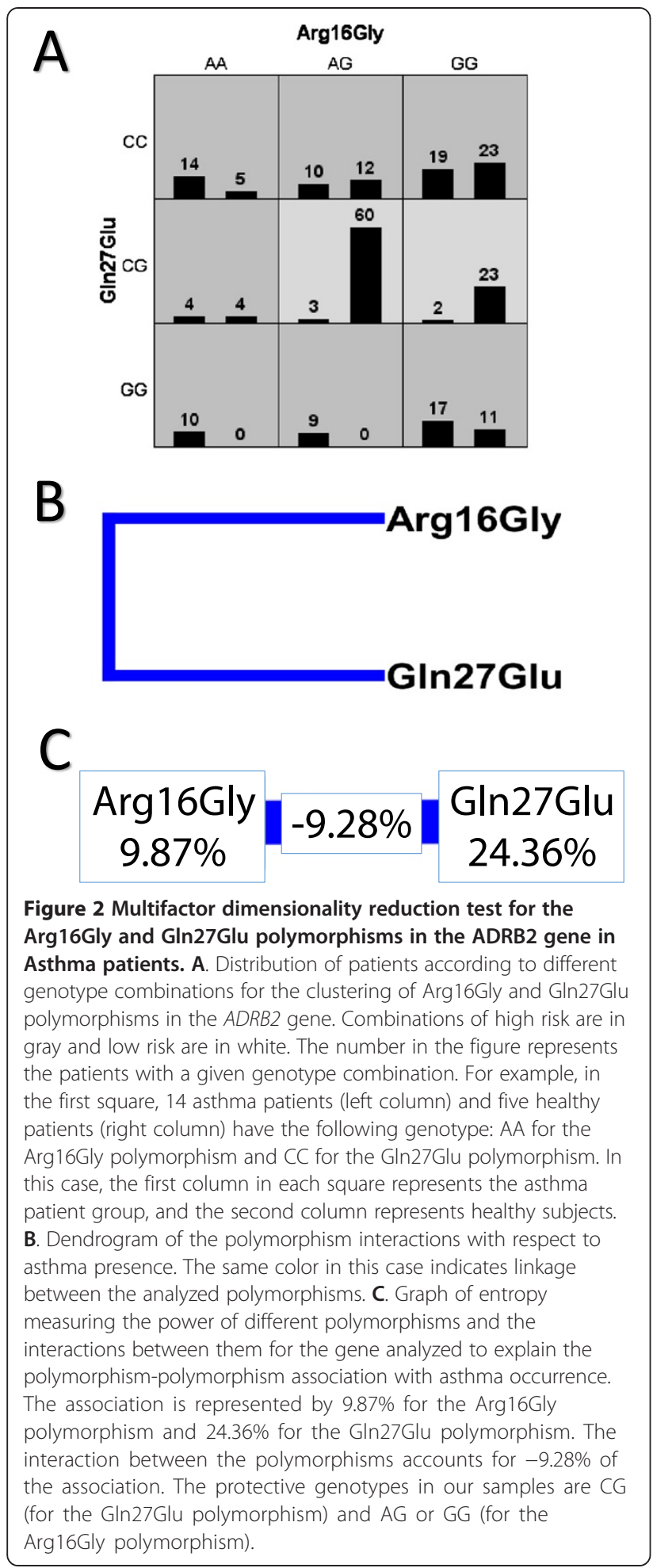

may account for some of the variability in the responses to treatment with ADRB2 agonists and may contribute to the increased mortality in select patient populations, such as cystic fibrosis patients [31]. Several studies have examined the $A D R B 2$ gene as a risk factor associated with bronchodilator response [38-40] but not as a risk factor associated with asthma prevalence within a population.

The allelic frequencies of the Arg16Gly and Gln27Glu SNPs vary with ethnicity [41,42]. The reported allele frequencies for Arg16 in the Caucasian, African American and Asian asthmatic populations were $0.39,0.50$ and 0.40 , respectively, while for Gln27, the reported frequencies were $0.57,0.73$ and 0.80 , respectively [41]. In the present study, the allelic frequencies of Arg16 were 0.53 in the asthma group and 0.27 in healthy subjects. For the Gln27 allele, the allelic frequencies were 0.67 and 0.33 in the asthma group and the healthy subjects, respectively. We observed that the frequencies found in our study are similar to those found in the African American and Caucasian populations.

The Arg16Gly and Gln27Glu polymorphisms cause differential agonist-stimulated down-regulation of the receptor in transfected cell systems, including human airway smooth muscle cells $[43,44]$. Many previous studies have investigated possible associations between asthma and polymorphisms in the coding region of the ADRB2 gene, particularly the Arg16Gly and Gln27Glu SNPs; however, these studies have yielded conflicting results [38-40,45-48].

In the present study, associations between the Arg16Arg and Gln27Gln genotypes and susceptibility to asthma were observed.

The Arg16Arg genotype was more frequent in asthma patients than in healthy subjects; the opposite correlation was observed for the homozygous Glu16Glu genotype showing that individuals with the former genotype have an increased susceptibility to the development of asthma. The Gln27Gln and Gln27Glu genotypes were indirectly related to the occurrence of asthma by the fact that the Glu27Glu genotype had a protective effect against asthma. Reinforcing this finding, elevated serum IgE levels have been found in patients carrying the Arg16 and Gln27 homozygous genotypes [49].

Our results contradicted previous data from studies of Japanese [50], African American [51] and North Indian [52] populations but agreed with other studies of Canadian [46], Chinese [53] and British populations [54], as well as a study of African American children [55]. This discrepancy may be the result of racial differences [48].

As expected, the results of the haplotype analysis showed that the haplotype Arg16Arg-Gln27Gln was associated with greater risk and that the Gly16Gly-Glu27Glu haplotype was protective. The haplotype Arg16ArgGln27Gln is associated in general with a poor response to the $\beta 2$-AR agonist and low levels of $\beta 2$-AR expression. In addition, the good response to exogenous agonists is reflected in a good response to endogenous agonists and a protective effect against asthma [56]. 
In a case-control study in the North Indian population, the Gly16Gly genotype conferred a decreased risk of asthma $(\mathrm{OR}=0.65 ; 95 \%$ IC $=0.41-1.02$; p-value $=0.049)$, while the Gln27Glu polymorphism was not associated with asthma in this population [38]. In our study, we observed a positive association between the Arg16Gly polymorphism and asthma prevalence, but the association is weak. These data do not corroborate another study in a Chinese population in which the Arg16Gly polymorphism was not associated with genetic susceptibility to childhood asthma [39]. A contrasting study showed different evidence: increased risk of nocturnal asthma in Egyptian children was associated with the Gly/Gly genotype of the Arg16Gly polymorphism $(\mathrm{OR}=3.2 ; 95 \% \mathrm{CI}=1.3-7.7$; p-value $=0.03)$ [40]. In this Egyptian study, as in previous studies, the Gln27Glu polymorphism did not show evidence of association with asthma. In this study, the population analyzed should be considered an important environmental factor that interacts with the polymorphisms in the $A D R B 2$ gene.

Specific data can be reviewed for the polymorphismassociated responses to short- and long-acting $\beta_{2}$-agonists. For long-acting $\beta_{2}$-agonists, results have shown no positive association between the Arg16Gly polymorphism and bronchodilation, but the Arg16 allele was associated with poor asthma control [57]. Contrasting results were observed in a Chinese population study. In that study, a significantly higher bronchodilator response was observed in patients with the homozygous genotype 46A/A $(13.40 \% \pm 3.48 \%)$ compared with those patients with the homozygous genotype $46 \mathrm{G} / \mathrm{G}(7.25 \% \pm 3.11 \%)$ and the heterozygous genotype $46 \mathrm{~A} / \mathrm{G}(7.39 \% \pm 3.14 \%) \quad(\mathrm{p}<0.0001)$ [58]. To determine the effects of the polymorphisms on asthma response to bronchodilators, new studies should be performed that include different populations, higher sample numbers and a complete $A D R B 2$ gene polymorphism analysis. For the direct response to methacholine, no association was found [59].

Based on the data, no consensus has been reached on the relationship between the identified $A D R B 2$ genetic variations and asthma. The causal alleles that are common in most ethnic groups may have differential effects because of interactions with the environment and/or other genetic variants that are unique to certain ethnic groups. The interpretation of the findings of the genetic association studies of the ADRB2 polymorphisms is complicated by the inadequate measurement of environmental exposures and differences in the allele and haplotype frequencies of the $A D R B 2$ gene and asthma severity among different racial groups. The complexity of the observed genotype-response effects limits their clinical applications [60]. In this context, our study has several strengths and limitations: our sample size may be considered small; there is no control for environmental factors; only two polymorphisms were analyzed; the Brazilian population is admixed; and a region with a specific genotype combination associated with risk may also be associated with a peculiar environmental factor.

The contradictory findings in studies of literature, including the present manuscript, may be associated by: (i) difference in approach to clinical management between centers, (ii) criteria for diagnosis of asthma, (iii) enrolled population of patients (atopic and non-atopic), (iv) population analyzed considering ethnic differences that can alter the genotypic frequency of polymorphisms, (v) clinical variables considered as risk factor (IgE values changed, lung function test, time to diagnosis, evidence of reversibility on spirometry), (vi) presence of non-reported comorbidities, (vii) the characterization of patients taking into account the referral center, whereas non-random sampling for the clinical severity of asthma; (viii) technique for evaluation of polymorphisms in the $A D R B 2$ gene may have, on rare occasions, erroneous results.

In conclusion, our data show that the Gln27Glu and Arg16Gly polymorphisms of the beta 2-adrenergic receptor gene play an important role in asthma prevalence and severity and are a potential tool for risk analysis in our population. The results reveal the influence of each polymorphism alone and together as a haplotype.

\section{Abbreviations}

ADRB2: Beta-2-adrenergic receptor; cAMP: Cyclic adenosine monophosphate; Cl: Confidence interval; OEGE: Online Encyclopedia for Genetic Epidemiology; SPSS: Statistical Package for the Social Sciences; Unicamp: State University of Campinas; $\beta 2 A R: \beta 2$ receptors.

\section{Competing interests}

The authors declare that they have no competing interests.

\section{Authors' contributions}

CZP, FALM: made substantial contributions to conception and design, acquisition of data, and analysis and interpretation of data; involved in drafting the manuscript and revising it for critically important intellectual content. JDR, CSB: made substantial contributions to conception and design, acquisition of data, and analysis and interpretation of data; involved in drafting the manuscript and revising it for critically important intellectual content. In addition, they have given final approval for the publishing of this version. All authors read and approved the final manuscript.

\section{Acknowledgments}

Financing agency: CAPES - Coordination for Higher Level Graduate Improvement (PICDT Scholarship) and Fapesp - Fundação de Amparo à Pesquisa do Estado de São Paulo (\#2011/18845-1).

Adyléia Dalbo Toro - Center for Investigation in Pediatrics, Pediatrics Department, University of Campinas, São Paulo, Brazil.

Genetic screening: http://www.laboratoriomultiusuario.com.br.

Received: 23 August 2013 Accepted: 14 January 2014

Published: 5 February 2014

\section{References}

1. Global Initiative for Asthma (GINA): A pocket guide for asthma management and prevention (for adults and children older than 5 years). 2012. Available from: www.ginasthma.com.

2. Worldwide variation in prevalence of symptoms of asthma, allergic rhinoconjunctivities, and atopic eczema: ISACC: The International Study of 
asthma and Allergies in Childhood (ISAAC) - Steering Committee. Lancet 1998, 351(111):125-132.

3. Anandan C, Nurmatov $U$, van Schayck OC, Sheikh A: Is the prevalence of asthma declining? Systematic review of epidemiological studies. Allergy 2010, 65(2):152-167.

4. Brasil. Ministério da Saúde. Secretaria nacional de Ações Básicas: Estatísticas de Saúde e Mortalidade. Braślia: Ministério da Saúde; 2005.

5. Hogg A: Asthma in children. InnovAiT 2011, 4(3):160-170.

6. Wedes SH, Khatri SB, Zhang R, Wu W, Comhair SA, Wenzel S, Teague WG, Israel E, Erzurum SC, Hazen SL: Noninvasive markers of airway inflammation in asthma. Clin Transl Sci 2009, 2(2):112-117.

7. Dodig S, Richter D, Zrinski-Topić R: Inflammatory markers in childhood asthma. Clin Chem Lab Med 2011, 49(4):587-599.

8. Kauffmann F, Castro-Giner F, Smit LAM, Nadif R, Kogevinas M: Gene-environment interactions in occupational asthma. In Occupational Asthma. Edited by Sigsgaard T, Heederik D. Basel: Birkhäuser; 2010:205-228.

9. Cookson WO, Moffatt MF: Genetics of complex airway disease. Proc Am Thorac Soc 2011, 8(2):149-153.

10. Barnes KC: Genetic studies of the etiology of asthma. Proc Am Thorac Soc 2011, 8(2):143-148.

11. Fireman P: Understanding asthma pathophysiology. Allergy Asthma Proc 2003, 24(2):79-83.

12. Thakkinstian A, McEvoy M, Minelli C, Gibson P, Hancox B, Duffy D, Thompson J, Hall I, Kaufman J, Leung TF, Helms PJ, Hakonarson H, Halpi E, Navon R, Attia J: Systematic review and meta-analysis of the association between \{beta\}2-adrenoceptor polymorphisms and asthma: a HuGE review. Am J Epidemiol 2006, 162(3):201-211.

13. NCBI: National Center for Biotechnology Information. www.ncbi.nlm.nih.gov/

14. Hawkins GA, Weiss ST, Bleecker ER: Clinical consequences of ADRbeta2 polymorphisms. Pharmacogenomics 2008, 9(3):349-358.

15. Johnson M: The beta-adrenoceptor. Am J Respir Crit Care Med 1998, 158:S146-S153.

16. Hadcock JR, Malbon CC: Down-regulation of beta-adrenergic receptors: agonist-induced reduction in receptor mRNA levels. Proc Natl Acad Sci USA 1998, 85:5021-5025.

17. Nishikawa M, Mark JC, Barnes PJ: Effect of short- a long-acting beta-2adrenoceptor agonists on pulmonary beta-2-adrenoceptor expression in human lung. Eur I Pharmacol 1996, 318:123-129.

18. Kobilka BK, Frielle T, Dohlman HG, Bolanowski MA, Dixon RA, Keller P, Caron MG, Lefkowitz RJ: Delineation of the intronless nature of the genes for the human and hamster beta-2-adrenergic receptor and their putative promoter regions. J Biol Chem 1987, 262:7321-7327.

19. Henderson R, Baldwin JM, Ceska TA, Zemlin F, Beckmann E, Downing KH: Model for the structure of bacterorhodopsin based on high-resolution electron cyro-microscopy. J Mol Biol 1990, 213:899-929.

20. Barnes PJ, Liew FY: Nitric oxide and asthmatic inflammation. Immunol Today 1995, 16(3):128-130.

21. Bhagat R, Kalra S, Swystun VA, Cockcroft DW: Rapid onset of tolerance to the bronchoprotective effect of salmeterol. Chest 1995, 108:1235-1239.

22. Cheung D, Timmers MC, Zwinderman AH, Bel EH, Dijkman JH, Sterk PJ: Long terms effect of a long-actin beta-2-adrenoceptor agonist, salmeterol, on airway hiperresponsiveness in patients with mild asthma. N Engl J Med 1992, 327:1198-1203.

23. Van Veen A, Weller FR, Wierenga EA, Jansen HM, Jonkers RE: A comparison of salmeterol and formoterol in attenuating airway responses to short-acting beta-2-agonists. Pulm Pharmacol Ther 2003, 16:153-161.

24. Yates DH, Kharitonov SA, Barne JP: An inhaled glucocorticoid does not prevent tolerance to the bronchoprotective effect as a long-acting inhaled beta-2-agonist. Am J Respir Crit Care Med 1996, 154:1603-1607

25. Liggett SB, Raymond J: Pharmacology and molecular biology of adrenergic receptors. Baillieres Clin Endocrinol Metab 1993, 7(2):279-306.

26. Kume H, Hall IP, Washabau RJ, Takagi K, Kotlikoff MI: Beta-adrenergic agonists regulate $\mathrm{KCa}$ channels in airway smooth muscle by CAMP dependent and independent mechanisms. J Clin Invest 1994, 93:371-379.

27. Fenech A, Hall IP: Pharmacogenetics of asthma. J Clin Pharmacol 2002, 53:3-15.

28. Liggett, Stephen B: Molecular and genetic basis of $\beta$-adrenergic receptor function and regulation. Asthma 1997, 1:299-312

29. Liggett SB: Polymorphisms of the beta-2-adrenergic receptor and asthma. Am J Respir Crit Care Med 1997, 156(4-2):S156-S162.
30. Tan S, Hall IP, Dewar J, Dow E, Lipworth B: Association between beta-2adrenoceptor polymorphism and susceptibility to bronchodilator desensitization in moderately severe stable asthmatics. Lancet 1997 350(9083):995-999.

31. Marson FA, Bertuzzo CS, Ribeiro AF, Ribeiro JD: Polymorphisms in ADRB2 gene can modulate the response to bronchodilators and the severity of cystic fibrosis. BMC Pulm Med 2012, 12:50.

32. Dean AG, Sullivan KM, Soe MM: OpenEpi. Open Source Epidemiologic Statistics for Public Health, Version 2.3.1. www.openepi.com, updated 06/2011, accessed 04/2013.

33. Faul F, Erdfelder E, Buchner A, Lang AG: Statistical power analyses using G*Power 3.1: tests for correlation and regression analyses. Behav Res Methods 2009, 41:1149-1160.

34. Hahn LW, Ritchie MD, Moore JH: Multifactor dimensionality reduction software for detecting gene-gene and gene-environment interactions. Bioinformatics 2003, 19(3):376-382.

35. Ritchie MD, Hahn LW, Moore JH: Power of multifactor dimensionality reduction for detecting gene-gene interactions in the presence of genotyping error, mising data, phenocopy, and genetic heterogeneity. Genet Epidemiol 2003, 24(2):150-157.

36. Moore JH, Gilbert JC, Tsai CT, Chiang FT, Holden T, Barney N, White BC A flexible computational framework for detecting, characterizing, and interpreting statistical patterns of epistasis in genetic studies of human disease susceptibility. J Theor Biol 2006, 241(2):252-261.

37. Chung LP, Waterer $G$, Thompson PJ: Pharmacogenetics of $\beta 2$ adrenergic receptor gene polymorphisms, long-acting $\beta$-agonists and asthma. Clin Exp Allergy 2011, 41(3):312-326.

38. Birbian N, Singh J, Jindal SK, Singla N: Association of $\beta(2)$-adrenergic receptor polymorphisms with asthma in a North Indian population. Lung 2012, 190(5):497-504.

39. Zheng BQ, Wang GL, Yang S, Lu YQ, Liu RJ, Li Y: Study of genetic susceptibility in 198 children with asthma. Zhongguo Dang Dai Er Ke Za Zhi 2012, 14(11):811-814

40. Karam RA, Sabbah NA, Zidan HE, Rahman HM: Association between genetic polymorphisms of beta2 adrenergic receptors and nocturnal asthma in Egyptian children. J Investig Allergol Clin Immunol 2013, 23(4):262-266.

41. Weir TD, Mallek N, Sandford AJ, Bai TR, Awadh N, Fitzgerald JM, Cockcroft D, James A, Liggett SB, Paré PD: Beta 2-adrenergic receptor haplotypes in mild, moderate and fatal/near fatal asthma. Am J Respir Crit Care Med 1998, 158(3):787-791.

42. Xie HG, Stein CM, Kim RB, Xiao ZS, He N, Zhou HH, Gainer JV, Brown NJ, Haines JL, Wood AJ: Frequency of functionally important beta-2 adrenoceptor polymorphisms varies markedly among African-American, Caucasian and Chinese individuals. Pharmacogenetics 1999, 9(4):511-516.

43. Moore PE, Laporte JD, Abraham JH, Schwartzman IN, Yandava CN, Silverman ES, Drazen JM, Wand MP, Panettieri RA Jr, Shore SA: Polymorphism of the beta(2)-adrenergic receptor gene and desensitization in human airway smooth muscle. Am J Respir Crit Care Med 2000, 162(6):2117-2124.

44. Green SA, Turki J, Bejarano P, Hall IP, Liggett SB: Influence of $\beta 2$-adrenergic receptor genotypes on signal transduction in human airway smooth muscle cells. Am J Respir Cell Mol Biol 1995, 13(1):25-33.

45. Turki J, Pak J, Green SA, Martin RJ, Liggett SB: Genetic polymorphisms of the beta-2-adrenergic receptor in nocturnal and nonnocturnal asthma. Evidence that Gly16 correlates with the nocturnal phenotype. J Clin Invest 1995, 95(4):1635-1641.

46. Matheson MC, Ellis JA, Raven J, Johns DP, Walters EH, Abramson MJ: Beta2adrenergic receptor polymorphisms are associated with asthma and COPD in adults. J Hum Genet 2006, 51(11):943-951.

47. Asano K, Yamada-Yamasawa W, Kudoh H, Matsuzaki T, Nakajima T, Hakuno H, Hiraoka R, Fukunaga K, Oguma T, Sayama K, Yamaguchi K, Nagabukuro A, Harada Y, Ishizaka A: Association between beta-adrenoceptor gene polymorphisms and relative response to beta(2)-agonists and anticholinergic dr ugs in Japa-nese asthmatic patients. Respirology 2010, 15(5):849-854.

48. Fu WP, Zhao ZH, Zhong L, Sun C, Fang LZ, Liu L, Zhang JQ, Wang L, Shu JK, Wang XM, Dai LM: Relationship between polymorphisms in the $5^{\prime}$ leader cistron, positions 16 and 27 of the adrenergic $\beta 2$ receptor gene and asthma in a Han population from southwest China. Respirology 2011, 16(8):1221-1227.

49. Woszczek G, Borowiec M, Ptasinska A, Kosinski S, Pawliczak R, Kowalski ML: Beta2-ADR haplotypes/polymorphisms associate with bronchodilator response and total IgE in grass allergy. Allergy 2005, 60(11):1412-1417. 
50. Migita O, Noguchi E, Jian Z, Shibasaki M, Migita T, Ichikawa K, Matsui A, Arinami T: ADRB2 polymorphisms and asthma susceptibility: transmission disequilibrium test and meta-analysis. Int Arch Allergy Immunol 2004, 134(2):150-157.

51. Lima J, Holbrook JT, Wang J, Sylvester JE, Blake KV, Blumenthal MN, Castro M, Hanania N, Wise R: The C523A beta2 adrenergic receptor polymorphism associates with markers of asthma severity in African Americans. J Asthma 2006, 43(3):185-191.

52. Bhatnagar P, Gupta S, Guleria R, Kukreti R: Beta2-Adrenergic receptor polymorphisms and asthma in the Nor th Indian population. Pharmacogenomics 2005, 6(7):713-719.

53. Yin $\mathrm{KS}$, Zhang XL, Qiu YY: Association between b2-adrenergic receptor genetic polymorphisms and nocturnal asthmatic patients of Chinese Han nationality. Respiration 2006, 73(4):464-467.

54. Hall IP, Blakey JD, Al Balushi KA, Wheatley A, Sayers I, Pembrey ME, Ring SM, McArdle WL, Strachan DP: Beta2-adrenoceptor polymorphisms and asthma from childhood to middle age in the British 1958 birth cohort: a genetic association study. Lancet 2006, 368(9537):771-779.

55. Elbahlawan L, Binaei S, Christensen ML, Zhang Q, Quasney MW, Dahmer MK: Beta2-adrenergic receptor polymorphisms in African American children with status asthmaticus. Pediatr Crit Care Med 2006, 7(1):15-18.

56. Drysdale CM, McGraw DW, Stack CB, Stephens JC, Judson RS, Nandabalan K, Arnold K, Ruano G, Liggett SB: Complex promoter and coding region beta 2-adrenergic receptor haplotypes alter receptor expression and predict in vivo responsiveness. Proc Natl Acad Sci U S A 2000, 97:10483-10488.

57. Rebordosa C, Kogevinas M, Guerra S, Castro-Giner F, Jarvis D, Cazzoletti L, Pin I, Siroux V, Wjst M, Antò JM, de Marco R, Estivill X, Corsico AG, Nielsen R, Janson C: ADRB2 Gly16Arg polymorphism, asthma control and lung function decline. Eur Respir J 2011, 38(5):1029-1035.

58. Qiu $Y Y$, Zhang $X L$, Qin $Y$, Yin $K S$, Zhang DP: Beta(2)-adrenergic receptor haplotype/polymorphisms and asthma susceptibility and clinical phenotype in a Chinese Han population. Allergy Asthma Proc 2010, 31(5):91-97.

59. Manoharan A, Anderson WJ, Lipworth BJ: Influence of $\beta(2)$-adrenergic receptor polymorphism on methacholine hyperresponsiveness in asthmatic patients. Ann Allergy Asthma Immunol 2013, 110(3):161-164.

60. Hizawa N: Beta-2 adrenergic receptor genetic polymorphisms and asthma. J Clin Pharm Ther 2009, 34(6):631-643.

doi:10.1186/1710-1492-10-8

Cite this article as: de Paiva et al:: Asthma: Gln27Glu and Arg16Gly polymorphisms of the beta2-adrenergic receptor gene as risk factors. Allergy, Asthma \& Clinical Immunology 2014 10:8.

\section{Submit your next manuscript to BioMed Central and take full advantage of:}

- Convenient online submission

- Thorough peer review

- No space constraints or color figure charges

- Immediate publication on acceptance

- Inclusion in PubMed, CAS, Scopus and Google Scholar

- Research which is freely available for redistribution 